\title{
Implementation of Democratic Values at the Islamic Boarding School of Jagad 'Alimussirry Surabaya
}

\author{
P Bektisiwi \\ Islamic Building School of Jagad Alimussirry Surabaya, Indonesia \\ Email: Pangesthibektisiwi@gmail.com
}

\begin{abstract}
Islamic boarding schools are a community in which lecture, teacher, student, and Islamic boarding schools administrators live in one environment by basing Islamic religious values accompanied by general education instilled in this place. Islamic boarding schools have been known as traditional educational institutions which focus on religious education and focus all decisions on kiai who are central figures making the process of democratic education not going well because of authoritarianism. But at the islamic boarding school student boarding school im Alimussirry Surabaya does not use an authoritarian system, namely using a democratic system in its daily life. Because this boarding school is classified as a modern boarding school. Democracy will be formed when democratic values have developed widely, evenly, internalized and carried out as the attitude and behavior of all components of the Islamic Boarding School of Jagad 'Alimussiry Surabaya based on observations showing that life in Islamic Boarding School of Jagad 'Alimussirry Surabaya has implemented democratic values, it has been shown that there is a structured boarding house management, deliberative decision making and general elections to elect the president of the BES.
\end{abstract}

Keywords: Islamic boarding schools, Democratic, santri

\section{INTRODUCTION}

The values of democracy are habits that emerge as a form of democratic culture. Society accepts and implements democratic values in life will produce a culture of democracy. A culture of democracy in the community will be formed when democratic values have developed widely, evenly, lived and carried out as life attitudes and behaviors. In the end, a democratic culture will restore democratic values [1]. An effort that requires seriousness in realizing a concept that is able to provide changes to the implementation carried out. Creating a civil society means creating a concept that is able to provide changes to the implementation carried out. Creating civil society means creating a democratic culture, of course there is no support from various parties, especially educational institutions. One of them is a boarding school. Islamic boarding schools have been known as traditional educational institutions which only focus on religious learning. What is the Islamic Boarding School of Jagad 'Alimussirry Surabaya in instilling democratic values in order to realize a democratic culture.

Islamic Boarding School of Jagad 'Alimussirry Surabaya in reality most of its students are students who are studying and studying in college, including democratic learning.

And even more important is the attitude of democracy in the campus to become a daily conversation among students. Evidently, all elections in the world of campus must be based on a democratic system. Starting from the campus presidential election, the head of 
the organization to the perspective in deciding the problem. In essence, on all campuses the practice of democracy is a reference in the selection and decision of a case.

But inevitably, many students said they practiced a democratic system even though in reality they practiced the demograzy system. Many of the actions taken by students culminate in the demograzy system. Violence and chaos in demonstrating are the main products to convey aspirations.

Based on the above, the author feels that there is a strong urge to raise issues related to democracy in the lives of Islamic boarding schools with santri who are educated in college.

From the results of observations at the Islamic Boarding School Student Boarding School 'Alimussirry Surabaya found that the boarding school adheres to a democratic system in carrying out the internal management structure of the santri. For this reason, the author tries to explore the knowledge of the implementation of democratic values in the Islamic Boarding School Student Boarding School 'Alimussirry Surabaya.

\section{DISCUSSION}

\section{A. The Nature of Democracy}

Democracy is the Government of the people, by the people and for the people. In other words, in democracy there is broad public participation in making decisions that affect community life.

Democracy also has closeness to Islamic values. An example is that Islam has several principles regarding democracy, namely:

1. Shura Is a principle about how to make decisions. It is clear that deliberation is needed as a material consideration and shared responsibility in each issue a decision.

2. Al-alah is justice, meaning that in enforcing the law, including recruitment in various government positions, it must be done fairly and wisely.

3. Al-Musawah is a parallel, meaning that no party feels higher than the others so they can impose their will.

4. Al-Amanah is the attitude of fulfilling the trust that someone gives to others.

5. Al-Masuliyyah is the responsibility. power as a mandate has two meanings, namely a mandate that must be accounted for in front of the people and also a mandate that must be accounted for before God. With the realization of the principle of accountability (al-masuliyyah), it is hoped that each person will try to provide the best for the wider community.

6. Al-Hurriyyah is freedom, meaning that every person, every citizen is given the right and freedom to express his opinion.

From the above explanation, it can be understood that democracy is the openness of the views or opinions of the people in advancing a country that adheres to the notion of democracy based on the people. In this paper, it is illustrated that those who occupy positions as leaders or presidents are administrators (kiai) while their countries are Islamic Boarding School Students 'Alimussirry Surabaya. So the people referred to in this writing are santri Islamic Boarding School Students 'Alimussirry Surabaya in expressing their views or voices for the advancement of education and management order (santri management structure) Islamic Boarding School Students“ Alimussirry Surabaya.

\section{B. Democratic Values}

Henry B mayo in his book Introduction to Democratic Theory details some of the values contained in democracy, namely:

1. Resolve problems peacefully and institutionalize.

2. Ensure the implementation of peaceful change in a society that is changing.

3. Organize leader changes regularly.

4. Limiting the use of violence to a minimum level. 
5. Recognize and consider the existence of diversity. Guarantee the upholding of justice.

\section{The nature of Islamic boarding schools}

Islamic boarding schools are Indonesian educational institutions to explore the knowledge of Islam. Islamic boarding schools are in the form of dormitories, which are also places of residence for students. According to [2] Islamic Boarding Schools have 5 basic elements, namely; 1 . Pondok as a dormitory for mukim santru, 2. Mosque as a place for conducting teaching and worship education, 3 . Al-Qur'an, Hadith, and classical Islamic books as guidelines in teaching, 4. Santri as students or students, 5. Kiai and administrators as leaders, teachers and role models.

Islamic boarding schools also have 2 types, namely traditional Islamic boarding schools which tend to be authoritarian and modern Islamic boarding schools that tend to be democratic. Traditional Islamic boarding schools are Islamic education and teaching institutions that still use the old system, namely those who have not used modern education yet, still use the sorogan or bandongan system.

\section{Implementation of Democratic Values at the Islamic Boarding School of Jagad 'Alimussirry Surabaya}

The implementation of democratic values at the Islamic Boarding School Student Boarding School 'Alimussirry Surabaya is shown by various things carried out in the Islamic boarding school. The simplest implementation of democracy is in a number of study subjects conducted at the S1 level and all study subjects at the S2 level using a system of discussion, presentation and question and answer, so that students are free to voice their opinions. Then including the existence of a good management structure, then there is an official organization in the lodge. The management of the lodge is structured well with the division of tasks ranging from the president director to several directors including director of education, director of human resource development, director of publishing, laziz director, director of public relations, director of writing and development institutions and equipped with board management.

In addition, there is an official organization in the lodge, the Santri Executive Board (BES). In the BES management a general election is held to determine the president of the BES, then the selection of BES members is carried out. To make BES activities, of course also through meetings and get proposals from BES members so that deliberations take place so that activities can be carried out properly. Then if there are problems discussed in deliberation on the BES or the director to achieve the best solution, but if it has not been resolved then it is brought to the president director, so that everything is done structurally. Even so, if it is going to do activities or when there are problems, it is also openly explained to the community, so that it is in accordance with the wishes of the community or santri.

The implementation of democracy in the Islamic Boarding School Student Boarding School 'Alimussirry Surabaya has not been carried out purely because in some democratic practices there is still interference from the management of the lodge or kiai. This is like what happened when the presidential election of BES was in determining the $50 \%$ victory based on the votes of the clerics, $20 \%$ based on the votes of the director and only $30 \%$ of the votes from the santri. Such practices show that the implementation of democracy has not been carried out purely, although there are also some activities that are purely in accordance with the will of the people.

\section{CONCLUSION}

Democracy is a system of government of the people by the people and for the people. In this paper, it is illustrated that those who occupy positions as leaders or presidents are administrators (kiai) while their countries are 
Islamic Boarding School Students 'Alimussirry Surabaya. So the people referred to in this writing are santri Islamic Boarding School Students 'Alimussirry Surabaya in expressing their views or voices for the advancement of education as well as the management order (santri management structure) Islamic Boarding School Students uss Alimussirry Surabaya. Life at Islamic Boarding Schools Students of Al-Sussirry Surabaya have implemented democratic values which have been shown to have structured boarding houses, deliberative decision making and general elections to elect the president of the BES. The implementation of democracy in the Islamic Boarding School Student Boarding School 'Alimussirry Surabaya has not been carried out purely because in some democratic practices there is still interference from the management of the lodge or kiai.

\section{REFERENCES}

[1] M. Arifin, "Definisi Pondok Pesantren", Jakarta: Ghalia Indonesia, 2006.
[2] M. Nawawi, "Pengertian Pondok Pesantren Plus”, Bandung: Ganeca, 2000.

[3] M. Bakry, "Pemahaman Demokrasi dalam Pondok Pesantren Plu", Jakarta: PT BPK Gunung Muli, 2012.

[4] R. A. Candrayana, "Implementasi Demokrasi di Pondok Pesantren Mahasiswa Al-Jihad Surabaya", unpublished, Surabaya: PPs Universitas Negeri Surabaya, 2014.

[5] Mustuhu, "Pembaharuan dalam Kebijakan Pesantren", Klaten: Gaya Baru, 2000.

[6] C. Toha, "Kapita Selekta Pendidikan Islam", Yogyakarta: Pustaka Pelajar, 1996.

[7] A. Yahya, "Demokrasi atau Demograzy di Kampus", 2012 [accessed on March 23rd http://www.tribunnews.com/tribunners/2012/0 2/16/demokrasi-atau-demograzy-di-kampus].

[8] Tim, "Pengertian Nilai Secara Umum dan Menurut Para Ahli”, 2017 [accessed on March 24th2018,http://www.sumberpengertian.co/pen gertian-nilai-menurut-para-ahli] 